\title{
ENHANCEMENT OF GROWTH OF LENTINUS CRINITUS IN SOIL USING BENOMYL AND VEGETABLE OIL
}

\author{
Kátia M.G. Machado ${ }^{1,2 *}$; Dácio R. Matheus ${ }^{3}$; Tatiana A. Rodrigues ${ }^{1}$; Vera L.R. Bononi ${ }^{3}$ \\ ${ }^{1}$ Fundação para o Desenvolvimento da Pesquisa Agropecuária/FUNDEPAG; ${ }^{2}$ Curso de Ciências Biológicas, Universidade \\ Católica de Santos, UniSantos, Santos; ${ }^{3}$ Seção de Micologia e Liquenologia, Instituto de Botânica, São Paulo, SP \\ Submitted: October 09, 2005; Returned to authors for corrections: April 17, 2006; Approved: September 18, 2006

\begin{abstract}
In order to identify alternatives for soil fumigation in bioremediation process, the addition of benomyl and vegetable oil on the growth of $L$. crinitus and mitosporic fungi were evaluated. Benomyl can be used as an alternative to methyl bromide. Addition of vegetable oil favors the growth of L. crinitus.
\end{abstract}

Key words: benomyl, basidiomycetes, fungicide, soil bioremediation, laccase

Lentinus crinitus CCB274 has been selected for bioremediation of HCB-contaminated soils in São Vicente, São Paulo, Brazil. The growth of this fungus has been studied in bioreactors ( $400 \mathrm{~kg}$ of soil), where soil sterilization is achieved by fumigation with methyl bromide (7) and the addition of vegetable oil at the time of inoculation has been shown to increase hexachlorobenzene biodegradation (5). The use of methyl bromide poses an environmental risk (2), and its replacement is therefore desirable. The addition of growth inhibitors of mitosporic fungi may thus be an alternative to fumigation. Benomyl (Benlate) exerts a fungitoxic effect on most ascomycetous fungi (3) and has been added to culture media for the isolation of basidiomycetes because of the tolerance of this fungal group to this substance (10). In order to identify alternatives to fumigation, we evaluated the effect of the systemic fungicide benomyl and addition of vegetable oil on the growth of $L$. crinitus and mitosporic fungi.

L. crinitus CCB274 is deposited at the Basidiomycetes Culture Collection (CCB, Instituto de Botânica/SMA), São Paulo, Brazil. This fungus was isolated from decaying wood (8) and the culture has been maintained on $2 \%$ malt extract agar at $4^{\circ} \mathrm{C}$. Mitosporic fungi were isolated on $2 \%$ MEA during the growth of L. crinitus in bioreactors containing non-sterilized soils in a previous assay. Three morphologically distinct cultures were obtained and were identified as Aspergillus sp., Penicillium sp. and Pestalotiopsis guepinii by standard methods based on microscopy and identification keys. For the fungal growth on solid media, disks (5 $\mathrm{mm}$ ) were cut from the plates where the fungus had grown, inoculated in the center of a Petri dish containing $2 \%$ MEA plus different concentrations of benomyl $\left(5,15\right.$, and $\left.50 \mathrm{mg} \mathrm{L}^{-1}\right)$, and incubated at $28 \pm 1^{\circ} \mathrm{C}$ in triplicate. Fungal growth was determined by daily measurement of the radius $(\mathrm{cm})$ in each quadrant of the plate. Fungi grown in medium with acetone and without benomyl were used as control. Soil from São Vicente, S.P., Brasil (98.0\% sand, $2.3 \%$ organic matter, $0.06 \%$ nitrogen, $1.0 \mu \mathrm{g} \mathrm{g}^{-1}$ phosphorus

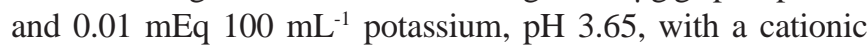
exchange capacity of $5.5 \mathrm{mEq} 100 \mathrm{~g}^{-1}$ soil) was used. Growth of mitosporic fungi was analyzed on rose bengal medium (1\% glucose, $0.5 \%$ peptone, $0.1 \% \mathrm{KH}_{2} \mathrm{PO}_{4}, 0.05 \% \mathrm{MgSO}_{4}, 0.0035 \%$ Rose bengal, $0.004 \%$ streptomycin sulfate, and $2 \%$ agar). Fifty grams of a mixture of soil and $\mathrm{CaSO}_{4}(90: 2.5$, dry weight) containing benomyl $\left(0,5\right.$ or $10 \mathrm{mg} \mathrm{kg}^{-1}$ soil) was placed in $200-\mathrm{mL}$ flasks in triplicate. L. crinitus grown in supplemented sugar-cane bagasse (6) was inoculated (2.5\% soil dry weight). During inoculation, $5 \%$ of a suspension of vegetable oil and Tween 20 (1:0.1) was added and the cultures were incubated at $28 \pm 1^{\circ} \mathrm{C}$. At 20 and 47 days samples were removed for the measurement of fungal biomass and laccase activity. The same parameters were evaluated in nonsterilized soil inoculated with inactivated $L$. crinitus biomass (sterilized at $120^{\circ} \mathrm{C}$ for 1 hour). L. crinitus inoculated into soil sterilized by tyndallization $\left(100^{\circ} \mathrm{C}, 1\right.$ hour, 3 days $)$ without benomyl

\footnotetext{
* Corresponding author. Mailing address: Curso de Ciências Biológicas, Centro de Ciências da Educação, Universidade Católica de Santos, Av. Conselheiro Nébias, 300, Santos. Cep.11015-002, Brazil. Tel.: (+5513) 32055555. E-mail: katia@ unisantos.br
} 
was used as control. To determine the influence of vegetable oil on the establishment of $L$. crinitus in nonsterilized soil, oil and Tween 20 suspension was added 20 days after inoculation of the basidiomycete, in one treatment only. The flasks receiving the suspension at the time of inoculation were used as controls. All experiments were carried out in triplicate. Fungal biomass was estimated based on the measurement of ergosterol (9). The enzymatic extract was obtained from soil samples using $50 \mathrm{mM}$ sodium acetate buffer (1:5), $\mathrm{pH} 4.5$, after shaking (1 hour, $90 \mathrm{rpm}$ ) and filtration (45 $\mu \mathrm{m})$. Laccase activity was determined by monitoring the increase in absorbance at $420 \mathrm{~nm}$ (4). One enzyme unit was defined as an activity producing $1 \mu \mathrm{mol}$ oxidized ABTS per minute using an extinction coefficient of $43.2 \mathrm{mM}^{-1} \mathrm{~cm}^{-1}(2)$.

L. crinitus was inhibited by about $34 \%$ at a benomyl concentration of $5 \mathrm{mg} \mathrm{L}^{-1}$ when cultured on solid medium. Inhibition of about $66 \%$ and $92 \%$ was observed when 15 and $50 \mathrm{mg} \mathrm{L}^{-1}$ of the fungicide, respectively, were added. The mitosporic fungi Penicillium sp., Aspergillus sp. and Pestalotiopsis guepinii only grew on media without benomyl. These results confirm the semi-selective effect of benomyl which is toxic to most ascomycetes. Mitosporic fungal counts in soil were $1.28 \times 10^{7} \mathrm{CFU}$. The efficiency of 5 and $10 \mathrm{mg}$ benomyl $\mathrm{kg}^{-1}$ soil to control the native mitosporic fungal microbiota and to favor the growth of basidiomycetes in nonsterilized soil was evaluated (Table 1). In treatments in which inactivated $L$. crinitus inoculum was used, benomyl significantly inhibited the growth of mitosporic fungi. Laccase activity was not detected in the treatments that received the inactivated $L$. crinitus inoculum. A direct relationship between laccase activity and benomyl concentration was observed, supporting the role of this fungicide in favoring the basidiomycete. The determination of fungal biomass based on ergosterol production did not permit the distinction between basidiomycetes and other fungi. However, when the effect of benomyl on the growth of mitosporic fungi is considered, the increase in ergosterol in the presence of $5 \mathrm{mg}$ benomyl $\mathrm{kg}^{-1}$ may reflect the growth of $L$. crinitus. On the other hand, the biomass reduction observed in the presence of $10 \mathrm{mg}$ benomyl kg-1 soil may be due to the inhibitory effect of this fungicide on $L$. crinitus growth as observed on solid media. Colonization of non-sterilized soil by L. crinitus was favored when oil was added 20 days after inoculation of the basidiomycete (Table 2). Vegetable oil is an easily assimilated energy source. When applied at the beginning of incubation, the oil favored the growth of mitosporic fungi evidenced by ausence of laccase activity. Laccase activity was found to be the best indicator for the presence and activity of basidiomycetes in soil. Benomyl at the concentration of $10 \mathrm{mg}$ $\mathrm{kg}^{-1}$ can be used as an alternative to methyl bromide in soil bioremediation processes mediated by $L$. crinitus.
Table 2. Influence of the addition of vegetable oil on the growth of Lentinus crinitus CCB274 in non-sterilized soil after 47 days of incubation at $28 \pm 1^{\circ} \mathrm{C}$.

\begin{tabular}{lccc}
\hline Parameter & $\begin{array}{c}\text { Inoculation of } \\
\text { Lentinus crinitus }\end{array}$ & \multicolumn{2}{c}{$\begin{array}{c}\text { Addition of } \\
\text { vegetable oil }\end{array}$} \\
\hline & & $1^{\text {st }}$ day & $20^{\text {th }}$ day \\
\cline { 3 - 4 } Visual analysis & + & $73 \%$ & $80 \%$ \\
of soil colonization & & $79 \% \pm 13.6$ & $59 \% \pm 3.1$ \\
Ergosterol content & + (a) & $68 \% \pm 0.3$ & $60 \% \pm 1.9$ \\
& $-(b)$ & $1 \% \pm 0.1$ & $33 \% \pm 2.1$ \\
Laccase activity & + & $0 \%$ & $0 \%$ \\
\hline
\end{tabular}

(a) The percentages were calculated considering the growth of $L$. crinitus in sterilized soil in the absence of benomyl as $100 \%$.

(b) The percentages were calculated considering the growth of fungi in soil with heat-inactivated L. crinitus in the absence of benomyl as $100 \%$.

Control laccase activity $=133.3 \mathrm{U} \mathrm{L}^{-1}$.

The authors are greateful to Dra. Rosely A. P. Grandi of the Seção de Micologia e Liquenologia of the Instituto de Botânica de São Paulo for helping with the identification of the mitosporic fungi.

\section{RESUMO}

\section{Aumento do crescimento de Lentinus crinitus em solo usando benomil e óleo vegetal}

Para identificar alternativas para a fumigação de solo em processos de biorremediação, foi avaliada a adição de benomil 
e de óleo vegetal no crescimento de Lentinus crinitus e fungos mitospóricos. Benomil pode ser usado como alternativa ao brometo de metila. A adição de óleo vegetal favoreceu o crescimento de L. crinitus.

Palavras-chave: benomil, basidiomicetos, fungicida, biorremediação de solos, lacase

\section{REFERENCES}

1. Bourbonnais, R.; Paice, M.G. Veratryl alcohol oxidases from the lignin-degrading basidiomycete Pleurotus sajor-caju. Biochem. J., 255: 445-450, 1988.

2. BRASIL. Ministério do Meio Ambiente, dos Recursos Hídricos e da Amazônia Legal. Kalyva, M.; Hora, L.S. (Coord.). O Brasil e a proteção da camada de ozônio. Brasília, 1997, 35p.

3. Kososki, R.M.; Furlanetto, C.; Tomita, C.K.; Café-Filho, A.C. Efeito de fungicidas em Colletotrichum acutatum e controle da antracnose do morangueiro. Fitopatol. Bras., 26(3): 662-666, 2001.

4. Machado, K.M.G.; Matheus, D.R. Biodegradation of remazol brilliant blue R by ligninolytic enzymatic complex produced by Pleurotus ostreatus. Brazilian J. Microbiol., 2006 (in press).
5. Matheus, D.R.; Bononi, V.L.R. C/N ratio and vegetable oil to mineralize ${ }^{14} \mathrm{C}$-hexachlorobenzene by white-rot-fungi. In: Gavaskar, A.R. and Chen, A.S.C. (eds). Remediation of Chlorinated and Recalcitrant Compounds. Proceedings of The Third International Conference on Remediation of Chlorinated and Recalcitrant Compounds. Battelle Press, Columbus, 2002, p.2b-10, ISBN 157477-132-9

6. Matheus, D.R.; Bononi, V.L.R.; Machado, K.M.G.; Silva, R.R.; Rodrigues, T.A. Basidiomycetes growth in bioreactors to applied in HCB soil biorremediation. Proceedings of The Seventh International Symposium In Situ and on-site Bioremediation, Battelle Press, Orlando, 2003.

7. Okino, L.K.; Machado, K.M.G.; Fabris, C.; Bononi, V.L.R Ligninolytic activity of tropical rainforest basidiomycetes. World $J$. Microbiol. Biotechnol., 16: 889-893, 2000.

8. Silva, R.R. Ergosterol para determinação de biomassa dos fungos Lentinus crinitus Berk. e Psilocybe castanella Peck em biorremediação de solos. Rio Claro, 2004, 108p. (Master Degree. Instituto de Biociências. Universidade Estadual Paulista).

9. Thorn, R.G.; Reddy, C.A.; Harris, D.; Paul, E.A. Isolation of saprophytic basidiomycetes from soil. Appl. Environ. Microbiol. 62(11): 4288-4292, 1996. 